Arq. Bras. Med. Vet. Zootec., v.66, n.4, p.1197-1206, 2014

\title{
Dinâmica da população de coliformes durante a compostagem automatizada de dejetos líquidos de suínos
}

\author{
[Population dynamics during composting of fecal automated pig slurry] \\ M.F. Sá ${ }^{1}$, C. Aita ${ }^{2}$, A. Doneda $a^{1}$, S.B. Pujol ${ }^{1}$, R.R. Cantú ${ }^{1}$, I.V.C. Jacques ${ }^{3}$, \\ G.G. Bastiani ${ }^{3}$, P.D. Oliveira ${ }^{3}$, P.D. Lopes ${ }^{1}$ \\ ${ }^{1}$ Aluno de pós-graduação - Universidade Federal de Santa Maria - UFSM - Santa Maria, RS \\ ${ }^{2}$ Universidade Federal de Santa Maria - UFSM - Santa Maria, RS \\ ${ }^{3}$ Aluno de graduação - Universidade Federal de Santa Maria - UFSM - Santa Maria, RS
}

\begin{abstract}
RESUMO
Microrganismos presentes em dejetos de suínos podem contaminar o meio ambiente. Embora a compostagem seja preconizada como um método eficiente para reduzir este potencial poluidor dos dejetos, existem poucas informações de pesquisa sobre tal processo. O presente trabalho teve o objetivo de avaliar a eficiência da compostagem automatizada dos dejetos líquidos de suínos (DLS) na redução da população de coliformes, usados como indicadores de poluição fecal. Os DLS foram adicionados periodicamente, durante 106 dias, em substrato constituído pela mistura, em partes iguais, de maravalha e serragem. Foram efetuadas 14 adições de DLS, e em cada adição as leiras de compostagem eram revolvidas por meio de uma máquina especialmente desenvolvida para este fim. Foram avaliados dois tratamentos com três repetições, sendo um com e outro sem adição de ácido fosfórico aos dejetos, até pH 6,0. A adição de ácido visou reduzir as perdas de $\mathrm{N}$ por volatilização de amônia $\left(\mathrm{NH}_{3}\right)$ durante a compostagem. A avaliação da população de coliformes foi feita pela técnica do número mais provável (NMP), com uso do caldo Fluorocult, incubado a $37^{\circ} \mathrm{C}$ por $24 \mathrm{~h}$ e posterior leitura em luz ultravioleta. A população de coliformes fecais não foi afetada pela adição de ácido fosfórico. $\mathrm{O}$ processo de compostagem automatizada foi eficiente na redução de coliformes fecais, cuja população original passou de $4,2 \times 10^{10}$ para $1,2 \times 10^{5}$ ao final da compostagem (156 dias) sem adição de ácido e de $3,8 \times 10^{10}$ para $2,3 \times 10^{4}$ na compostagem com adição de ácido. Essa remoção de coliformes fecais, promovida pela compostagem automatizada dos dejetos líquidos de suínos, corresponde a 99,99\%.
\end{abstract}

Palavras-chave: E. coli, resíduos da suinocultura, tratamento de efluentes

\begin{abstract}
Microorganisms present in pig manure can contaminate the environment. Although composting is recommended as an efficient method to reduce the pollution potential of waste, there is little research information on this process. This study aimed to evaluate the efficiency of automated composting of pig slurry $(P S)$ in reducing the population of coliforms, used as fecal pollution indicators. The PS was added periodically during 106 days in substrate, with a mixture, in equal parts, of wood shavings and sawdust. There were 14 additions of PS and at each addition the compost windrows were revolved through a machine especially developed for this purpose. Two treatments with three replications were evaluated, one with and one without the addition of phosphoric acid to the slurry up to $\mathrm{pH}$ 6.0. The acid addition aimed to reduce $N$ losses through the volatilization of ammonia (NH3) during composting. Coliforms were evaluated by the technique of most probable number $(M P N)$ using the Fluorocult broth, incubated at $37^{\circ} \mathrm{C}$ for $24 \mathrm{~h}$ and subsequent reading in ultra violet light. The population of fecal coliforms was not affected by the addition of phosphoric acid. The automated composting process was effective in reducing faecal coliforms, whose original population decreased from $4.2 \times 10^{10}$ to $1.2 \times 10^{5}$ at the end of composting (156 days) without addition of acid and from $3.8 \times 10^{10}$ to $2,3 \times 10^{4}$ in compost with added acid. This removal of faecal coliforms, promoted by automated composting of pig slurry, corresponds to $99.99 \%$.
\end{abstract}

Keywords: E. coli, swine waste, effluent treatment

Recebido em 3 de setembro de 2012

Aceito em 16 de dezembro de 2013

E-mail: mariangelazoot@yahoo.com.br 


\section{INTRODUÇÃO}

A necessidade de aumentar a produção de carne e, ao mesmo tempo, reduzir os impactos negativos sobre o meio ambiente constitui um dos maiores desafios da suinocultura brasileira. Isso em razão do grande volume de dejetos líquidos produzidos pelos suínos, os quais permanecem confinados em todas as etapas do ciclo produtivo. A busca por novas alternativas para a reciclagem dos dejetos de suínos, que não envolvam o seu uso direto como fertilizante, deve ser abrangente, compreendendo todos os segmentos da cadeia produtiva e levando em consideração os conceitos de sustentabilidade ambiental. De acordo com Perdomo (2003), o processo de concentração da suinocultura se manteve crescente, e a estrutura fundiária, bem como a proporção de terras aptas à agricultura, permaneceu a mesma, gerando sobrecarga de dejetos por unidade de área nas propriedades.

Os dejetos de suínos constituem uma fonte potencial de nutrientes e, por isso, podem ser usados como fertilizantes orgânicos, o que, em muitas unidades criadoras, é um importante fator de produção (Barros et al., 2011). No entanto, uma grande variedade de bactérias patogênicas, como, por exemplo, E. coli e Salmonella sp., além de protozoários e helmintos, pode ser encontrada nos dejetos e representa uma ameaça à saúde pública (Wong et al., 2009). Isso porque tais organismos podem permanecer no ambiente por longos períodos de tempo, tanto nos locais onde os animais são criados quanto no solo das propriedades em que os dejetos são aplicados como fertilizantes para produzir alimentos (Semenov et al., 2010). Nessas condições, o risco de contaminação irá depender, em grande parte, da capacidade de sobrevivência dos microrganismos no ambiente (Jacobsen et al., 2012).

Uma das alternativas preconizadas para reduzir a população de microrganismos potencialmente patogênicos nos dejetos consiste na sua compostagem. Isso porque, neste processo, em que os dejetos são adicionados a substratos com elevada relação $\mathrm{C} / \mathrm{N}$, ocorre elevação da temperatura devido ao aumento da atividade microbiana aeróbia. Por isso, o revolvimento das pilhas de compostagem favorece a entrada de oxigênio, aumentando a taxa de respiração aeróbia e contribuindo para que o processo de sanitização seja mais eficiente (Cempirková et al., 2007). Quando o tempo de compostagem e a temperatura atingida no processo não forem satisfatórios, agentes patogênicos podem ainda estar presentes no composto final produzido. Além disso, a exposição de patógenos a temperaturas subletais pode permitir a sobrevivência prolongada desses agentes por meio da sua adaptação ao calor (Kim et al., 2009).

Microrganismos indicadores são usados para avaliar as condições sanitárias do produto final da compostagem (Santana et al., 2006). Eles pertencem a espécies encontradas no conteúdo intestinal do homem e de animais homeotérmicos $\mathrm{e}$, por isso, quando presentes num ambiente específico, fornecem informações sobre a sua contaminação com material de origem fecal (Franco et al., 2008). Os microrganismos indicadores são enterobactérias, em que $E$. coli é a bactéria fecal mais utilizada porque modela $o$ comportamento dos agentes patogênicos durante o tratamento de resíduos orgânicos, além de tolerar altas temperaturas ambientais (Elving, 2009).

A dinâmica da população de coliformes durante o processo de compostagem de dejetos de animais ainda é pouco estudada. O objetivo do presente trabalho foi avaliar esse aspecto durante a compostagem automatizada de dejetos líquidos de suínos em substrato constituído da mistura de maravalha e serragem.

\section{MATERIAL E MÉTODOS}

O trabalho foi realizado em escala piloto, no período de dezembro de 2011 a maio de 2012, em casa de vegetação do Departamento de Solos da Universidade Federal de Santa Maria, RS. No interior da casa de vegetação, cuja cobertura era de telhas transparentes, foram montadas duas estruturas em madeira, com dimensões de 4,0 x $1,0 \times 1,0 \mathrm{~m}$, pintadas à base de cal, fechadas lateralmente com taboas e revestidas internamente com lona de polietileno. Cada estrutura foi preenchida com a mistura de maravalha de eucalipto $(233 \mathrm{~kg}$ ) e serragem de madeiras diversas $(233 \mathrm{~kg})$, constituindo as duas leiras de compostagem. Os dejetos líquidos de suínos (DLS) utilizados na compostagem, provenientes de animais de terminação, criados em regime de confinamento total, foram obtidos 
no Setor de Suinocultura da Universidade Federal de Santa Maria.

O pH médio dos DLS sem adição de ácido fosfórico era de 7,6 $( \pm 1,09)$ e de 6,0 $( \pm 0,5)$ após a adição de ácido. Os DLS apresentaram teores médios de $2,27( \pm 0,86) \mathrm{kg} \mathrm{m}^{-3}$ de $\mathrm{N}$ total $(1,43$ $( \pm 0,47) \mathrm{kg} \mathrm{m}^{-3}$ de N amoniacal e $2,21( \pm 1,07) \%$ de matéria seca. As datas e quantidades de dejetos distribuídos sobre as leiras, num total de 3.936 litros de dejetos durante todo o experimento, estão apresentados na Tab.1.

Tabela 1. Quantidade adicionada de dejetos líquidos de suínos (DLS) nas leiras em cada data e número mais provável (NMP) de coliformes totais e fecais nos DLS, com e sem adição de ácido fosfórico

\begin{tabular}{|c|c|c|c|c|c|c|}
\hline \multirow[b]{2}{*}{ Data } & \multicolumn{2}{|c|}{ Adição de dejetos } & \multicolumn{2}{|c|}{ Coliformes totais } & \multicolumn{2}{|c|}{ Coliformes fecais } \\
\hline & $\mathrm{L}_{\text {leira }}{ }^{-1}$ & $\begin{array}{l}\mathrm{L} \mathrm{kg}^{-1} \\
\text { substrato }\end{array}$ & $\begin{array}{l}\log _{10} \text { NMP } \\
\mathrm{mL}^{-1} \mathrm{DLS}\end{array}$ & $\begin{array}{l}\log _{10} \text { NMP } \\
\mathrm{mL}^{-1} \mathrm{DLS}+ \\
\text { ácido } \\
\text { fosfórico }\end{array}$ & $\begin{array}{l}\log _{10} \text { NMP } \\
\mathrm{mL}^{-1} \mathrm{DLS}\end{array}$ & $\begin{array}{l}\log _{10} \text { NMP } \\
\mathrm{mL}^{-1} \mathrm{DLS}+ \\
\text { ácido } \\
\text { fosfórico }\end{array}$ \\
\hline $06 / 12 / 11$ & 685 & 1,47 & 6,52 & 6,52 & 6,52 & 6,52 \\
\hline $13 / 12 / 11$ & 685 & 1,47 & 6,10 & 6,15 & 6,10 & 6,00 \\
\hline 20/12/11 & 466 & 1,00 & 5,98 & 5,61 & 5,98 & 4,94 \\
\hline $28 / 12 / 11$ & 300 & 0,65 & 4,69 & 4,81 & 4,69 & 4,69 \\
\hline $03 / 01 / 12$ & 300 & 0,65 & 5,85 & 5,68 & 5,85 & 5,65 \\
\hline $10 / 01 / 12$ & 250 & 0,54 & 5,61 & 5,52 & 5,18 & 4,82 \\
\hline $17 / 01 / 12$ & 250 & 0,54 & 5,52 & 6,15 & 5,45 & 5,9 \\
\hline $24 / 01 / 12$ & 200 & 0,43 & 5,69 & 5,71 & 5,69 & 5,71 \\
\hline $31 / 01 / 12$ & 200 & 0,43 & - & - & - & - \\
\hline $08 / 02 / 12$ & 150 & 0,32 & - & - & - & - \\
\hline $15 / 02 / 12$ & 150 & 0,32 & 5,90 & 5,56 & 5,85 & 5,56 \\
\hline $22 / 02 / 12$ & 100 & 0,21 & 6,04 & 6,45 & 5,45 & 5,61 \\
\hline $06 / 03 / 12$ & 100 & 0,21 & 5,61 & 6,17 & 5,61 & 6,04 \\
\hline $21 / 03 / 12$ & 100 & 0,21 & 6,95 & 6,04 & 6,36 & 5,95 \\
\hline
\end{tabular}

A adição dos dejetos e o revolvimento das leiras foram efetuados com uma máquina revolvedora, especialmente desenvolvida para este fim, a qual era composta de dois helicoides acionados por um motor elétrico trifásico com potência de dois CV. Em cada adição dos DLS nas leiras de compostagem, a coleta deles foi realizada nas calhas adjacentes às baias onde ficavam alojados os animais, sendo que os DLS ficavam estocados nas referidas calhas por um período nunca superior a uma semana. Essa operação ocorria uma vez por semana, na véspera da aplicação dos dejetos, e permaneciam em caixas d'água nas imediações da casa de vegetação. A aplicação dos dejetos sobre as leiras foi feita uma vez por semana da seguinte maneira: com o auxílio de uma mangueira, acoplada a um cano de PVC e com quatro saídas, aplicava-se sobre o substrato de cada pilha a metade da quantidade de dejetos estipulada. Em seguida, a máquina revolvedora era passada sobre a leira, revolvendo-a até o final. Posteriormente, era aplicada a outra metade dos dejetos e passava-se novamente a máquina em sentido contrário. A cada semana, dois dias após a aplicação dos dejetos, realizava-se apenas o revolvimento das leiras, visando oxigenar a massa de compostagem e facilitar a perda de umidade.

Em cada leira foi avaliado um tratamento, com três repetições. Numa das leiras, os dejetos foram adicionados sobre a mistura de maravalha e serragem. O tratamento avaliado na outra leira constou da adição de ácido fosfórico aos DLS na caixa d' água, alguns minutos antes da sua aplicação. A quantidade de ácido utilizada foi definida com base em testes preliminares, a fim de se obter um $\mathrm{pH}$ final do dejeto próximo a 6,0. Para isso, aplicaram-se $3,5 \mathrm{~mL}$ de ácido $\mathrm{L}^{-1}$ de dejetos. $\mathrm{O}$ ácido utilizado possuía concentração de $85 \%\left(\mathrm{P}_{2} \mathrm{O}_{5}\right)$ e densidade de $1,6 \mathrm{~g} \mathrm{~cm}^{-3}$. Este tratamento foi realizado com o objetivo de reduzir as perdas de $\mathrm{N}$ por volatilização de $\mathrm{NH}_{3}$ durante a compostagem, o que foi objeto de um trabalho paralelo a este. Aos 106 dias do início do experimento, o material das leiras apresentou sinais de saturação, o que fez com que fosse encerrada a adição de DLS. Assim, dos 106 até o final do experimento (aos 156 dias), era efetuado 
apenas o revolvimento mecânico das duas leiras de compostagem a cada três dias.

Antes de cada aplicação de DLS nas leiras, uma amostra do material era coletada e colocada em frasco estéril, o qual era armazenado em caixa de isopor com gelo e levado ao laboratório para a mensuração de coliformes totais e fecais pelo método dos tubos múltiplos, determinando-se o número mais provável (NMP), em caldo Fluorocult e séries de cinco tubos.

Antes de cada aplicação dos DLS, eram coletadas duas amostras de cada repetição dos dois tratamentos, sendo uma a 20 e outra a $50 \mathrm{~cm}$ de profundidade nas leiras, totalizando 12 amostras. As amostras foram rotuladas e levadas para o laboratório, onde, de cada amostra úmida, foram pesados $10 \mathrm{~g}$ de composto, que foram adicionados a frascos snap-cap contendo $90 \mathrm{~mL}$ de água peptonada tamponada $0,1 \%$ estéril $(\mathrm{pH}$ 6,5), estabelecendo-se a diluição inicial de $10: 1\left(10^{-1}\right)$. Para cada amostra, foram feitas duas repetições, que foram colocadas em agitador mecânico horizontal durante 15 minutos. De cada diluição $10^{-1}$ era retirado $1 \mathrm{~mL}$, o qual era transferido para tubos de ensaio estéreis, contendo $9 \mathrm{~mL}$ de água peptonada tamponada $0,1 \%$ estéril, estabelecendo-se a diluição $10^{-2}$. Este procedimento foi repetido de modo sequencial até a diluição $10^{-5}$. Em seguida, alíquotas de $0,5 \mathrm{~mL}$ da suspensão de cada uma das diluições $\left(10^{-1}\right.$ até $\left.10^{-5}\right)$ foram transferidas para tubos de ensaio com tampa contendo $4,5 \mathrm{~mL}$ de meio de cultura de caldo Fluorocult estéril. Para cada uma das diluições seriais foram feitas duas séries de cinco tubos, as quais foram incubadas por $24 \mathrm{~h}$ em incubadora a $36,5 \pm 1^{\circ} \mathrm{C}$.

Consideraram-se como tubos positivos para coliformes totais aqueles em que o meio de cultura mudou da cor amarela para verdeazulada. Para coliformes fecais, os tubos que, ao receberem luz ultravioleta incidente, apresentassem fluorescência foram considerados positivos e, quando permanecessem com a coloração original (amarelo-clara), foram considerados negativos. O número mais provável (NMP) foi calculado de acordo com a tabela da Apha (2005), série de cinco tubos.

Além da análise de coliformes, foi feita a avaliação do $\mathrm{pH}$ do composto em cada coleta. Para isso, uma alíquota de $10 \mathrm{~g}$ de composto era adicionada a $120 \mathrm{~mL}$ de água destilada em um snap-cap, sendo a mistura submetida à agitação por 30min em agitador horizontal. Logo após, o $\mathrm{pH}$ foi lido no sobrenadante com pHmetro calibrado. A temperatura do composto também foi avaliada, por meio de uma sonda termopar do tipo K, acoplada a um termômetro digital. Foram tomados dois pontos de leitura diariamente, sendo um a aproximadamente $20 \mathrm{~cm}$ de profundidade a partir da superfície da leira e outro a aproximadamente $20 \mathrm{~cm}$ a partir do fundo, em direção à superfície, em três repetições para cada tratamento. Para o cálculo da umidade, foi pesada uma alíquota do composto, em latas de metal, a qual foi levada para estufa a $65^{\circ} \mathrm{C}$ até massa constante. Foram utilizados os aplicativos Statistica, SAS (SAS Institute 2003) e Excel para análise dos dados. Os dados obtidos foram logaritmizados e submetidos à análise de variância, e as médias comparadas pelos testes $\mathrm{F}$ e de Tukey $(\mathrm{P}<0,05)$, quando necessário.

\section{RESULTADOS E DISCUSSÃO}

O substrato inicial (maravalha + serragem), submetido ao processo de compostagem juntamente com os dejetos de suínos, apresentou uma população inicial de coliformes totais (CT) de 5,2 $\left(\log _{10} \mathrm{NMP} \mathrm{g}^{-1}\right)$. Como o substrato não foi esterilizado, a presença de coliformes totais, mesmo antes de se adicionarem os dejetos, deve ser de origem ambiental, em razão do contato da maravalha e da serragem com chuva, poeira, animais, etc. Com a adição dos dejetos, cuja população inicial de coliformes totais foi de 6,5 $\left(\log _{10}\right.$ NMP $\left.\mathrm{g}^{-1}\right)$, a população encontrada na mistura dos dejetos com o substrato aumentou para 7,1 $\left(\log _{10}\right.$ NMP g $\left.{ }^{-1}\right)$ na primeira amostragem realizada (Fig. 1)

A população de coliformes totais diminuiu na fase inicial da compostagem, atingindo entre $2 \mathrm{e}$ $5\left(\log _{10}\right.$ NMP g $\left.g^{-1}\right)$ aos 20 dias e permanecendo entre 2 e $3\left(\log _{10}\right.$ NMP $\left.\mathrm{g}^{-1}\right)$ na maior parte das amostragens realizadas a partir desta data, até o final do experimento. Nas duas últimas amostragens realizadas, nota-se uma tendência na redução de coliformes totais, sendo que, no encerramento do experimento, aos 156 dias, o tratamento em que os dejetos receberam ácido fosfórico apresentou uma população de $1,9\left(\log _{10}\right.$ NMP $\mathrm{g}^{-1}$ ), que foi significativamente menor do que o composto sem adição de ácido $\left(3,4 \log _{10}\right.$ $\left(\mathrm{NMP} \mathrm{g}{ }^{-1}\right)$ ). 


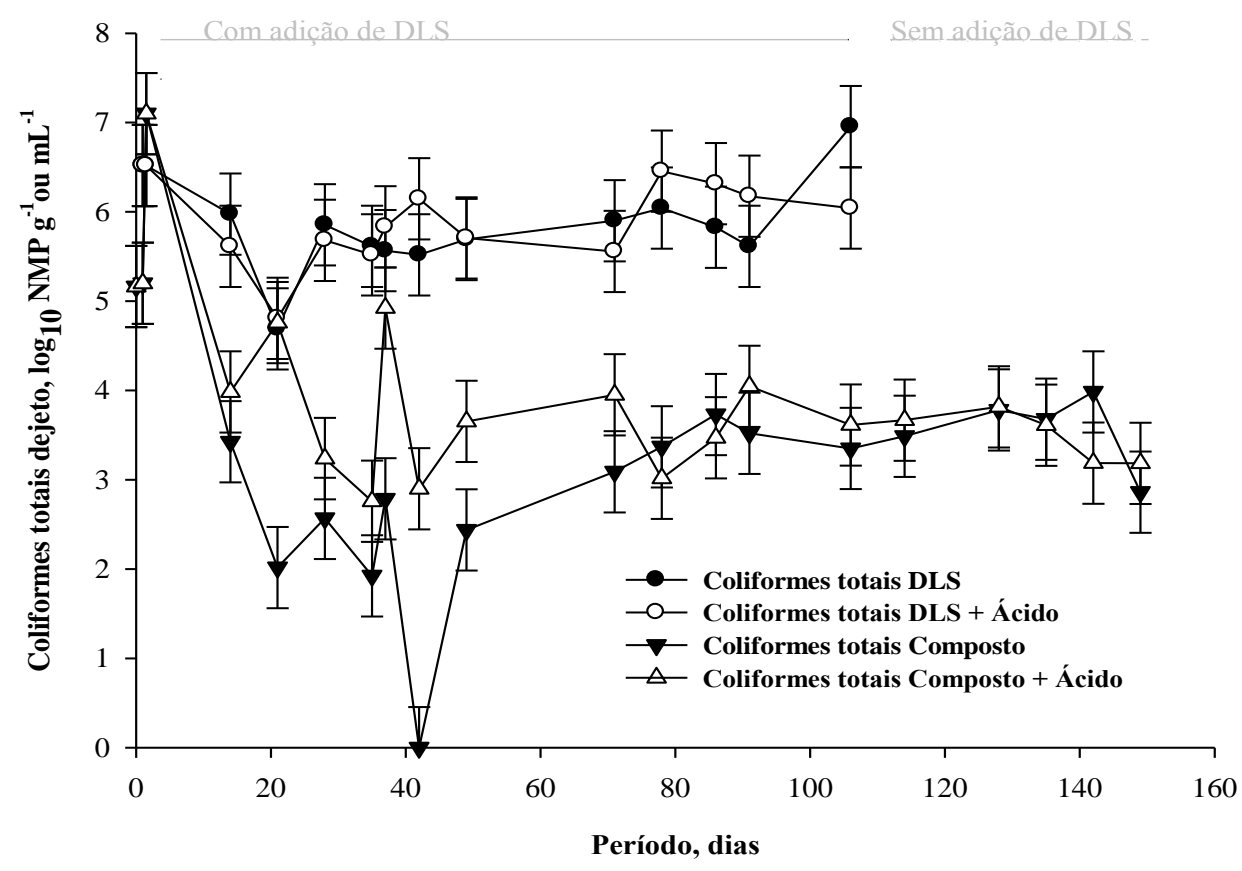

Figura 1. População de coliformes totais (CT) em dejetos líquidos de suínos (DLS), com e sem adição de ácido fosfórico antes da sua aplicação nas leiras de compostagem, e população de CT no composto obtido. As barras de erro representam o erro-padrão da média.

Ao se compararem os tratamentos em que os dejetos foram adicionados nas leiras de compostagem, com e sem adição de ácido fosfórico, observa-se que, até a nona coleta, (71 dias), houve diferença no número de CT entre os dois tratamentos, com o tratamento com adição de ácido apresentando os maiores valores. A partir da nona amostragem, os dois tratamentos não diferiram entre si. Quanto aos dejetos adicionados, observa-se que a população de CT variou dentro da faixa de 5 a $7\left(\log _{10} \mathrm{NMP} \mathrm{g}^{-1}\right)$ durante todo o experimento, sem diferenças entre adicionar ácido fosfórico ou não.

Um resultado inesperado a destacar refere-se ao fato de a população de CT não ter diminuído na maior parte das amostragens realizadas após ter cessada a adição de dejetos nas leiras, aos 106 dias. Essa persistência foi observada, tanto no composto que recebeu ácido como naquele sem ácido, apenas na última amostragem, a qual foi realizada aos 156 dias de compostagem, quando ocorreu um declínio no NMP de coliformes totais do composto sem adição de ácido. Esse resultado indica que as condições existentes nas leiras de compostagem, mesmo sem a adição de dejetos, foram suficientes para manter a população de coliformes totais.

O perfil de temperatura observado (Fig. 2) indica que, durante todo o período de compostagem, ocorreram três fases distintas, sendo a primeira até 30 dias, a segunda de 30 a 106 dias e a última de 106 a 156 dias, quando foi encerrado o experimento. $\mathrm{Na}$ primeira fase, observa-se que houve um aumento linear da temperatura das leiras durante os primeiros seis dias, a qual passou de aproximadamente $38^{\circ} \mathrm{C}$ para $61^{\circ} \mathrm{C}$. Esse aumento da temperatura, passando rapidamente da faixa mesofílica para a termofílica, tem sido observado em outros trabalhos (Kiehl, 2004; Valente et al., 2009) e se deve à liberação de calor durante o metabolismo dos microrganismos heterotróficos, cuja atividade é favorecida pela mistura dos dejetos de suínos, ricos em nitrogênio amoniacal, ao substrato utilizado (maravalha + serragem), cuja relação $\mathrm{C} / \mathrm{N}$ era elevada. Essa geração de calor pela atividade microbiológica durante o processo de oxidação da matéria orgânica é considerada 
de fundamental importância no tratamento de dejetos via compostagem, já que a maioria dos microrganismos potencialmente patogênicos é eliminada ou tem a sua população diminuída durante a fase termofílica (Valente et al., 2009). Por isso, a redução da população de coliformes totais observada na fase inicial da compostagem (Fig. 1) pode ser atribuída a este aumento da temperatura das leiras.

Ainda na primeira fase, observa-se que, durante os primeiros 20 dias, em que a temperatura das leiras se manteve em valores mais elevados, oscilando entre 38 e $65^{\circ} \mathrm{C}$, ocorreram maiores variações nos valores (Fig. 2). Aos sete dias, por exemplo, a temperatura média das pilhas, com e sem adição de ácido fosfórico, diminuiu de 60 para $45^{\circ} \mathrm{C}$ e logo aumentou novamente até atingir $61^{\circ} \mathrm{C}$ aos 10 dias. Do $10^{\circ}$ ao $12^{\circ}$ dia, a temperatura diminuiu para cerca de $50^{\circ} \mathrm{C}$ e aumentou novamente, até atingir o valor máximo observado no experimento, que foi de $65^{\circ} \mathrm{C}$ aos 14 dias. Esse comportamento pode ser explicado em razão dos revolvimentos efetuados nas leiras por meio da máquina revolvedora. A cada revolvimento efetuado, ocorre liberação de calor das pilhas, com forte impacto na redução da temperatura. Logo após essa operação, a temperatura se eleva novamente, até o próximo revolvimento. Todavia, isso é observado apenas durante as primeiras três semanas de compostagem, indicando que, após este período, a disponibilidade de carbono do substrato começou a limitar a atividade da população de heterotróficos e, mesmo com o revolvimento, não havia oscilação significativa da temperatura.
Na Fig. 2, observa-se que, no período após três semanas e até os 30 dias, ocorreu uma queda de, aproximadamente, $20^{\circ} \mathrm{C}$ da temperatura, quando iniciou a segunda fase em que a temperatura se manteve em valores próximos a $45^{\circ} \mathrm{C}$ até 106 dias, período em que cessou a adição de dejetos nas leiras. Isso reforça a hipótese de que a disponibilidade maior de carbono da mistura de maravalha + serragem, utilizada como substrato, ocorreu nas primeiras três semanas e que, após este período, a atividade microbiana foi sustentada pela adição de carbono por meio dos dejetos, já que estes eram adicionados semanalmente. Neste período, entre 30 e 106 dias, a temperatura das leiras superou a temperatura do ambiente em, aproximadamente, $15^{\circ} \mathrm{C}$ em média, o que demonstra a influência do substrato remanescente e, principalmente, dos dejetos como fontes de $\mathrm{C}$ e energia aos microrganismos, mantendo a sua atividade. $\mathrm{O}$ efeito dos dejetos na manutenção da atividade microbiana e, por consequência, na temperatura das leiras é comprovado ao se analisar o período entre 106 e 156 dias, na terceira fase do processo. Observa-se que, com a interrupção na adição de dejetos, aos 106 dias, a temperatura das leiras diminuiu gradativamente, aproximando-se cada vez mais dos valores da temperatura ambiente. Isso indica que, aos 150 dias, o composto atingiu a maturidade, já que a temperatura tem sido usada como um índice de maturação do composto (Kiehl, 2004; Valente et al., 2009).

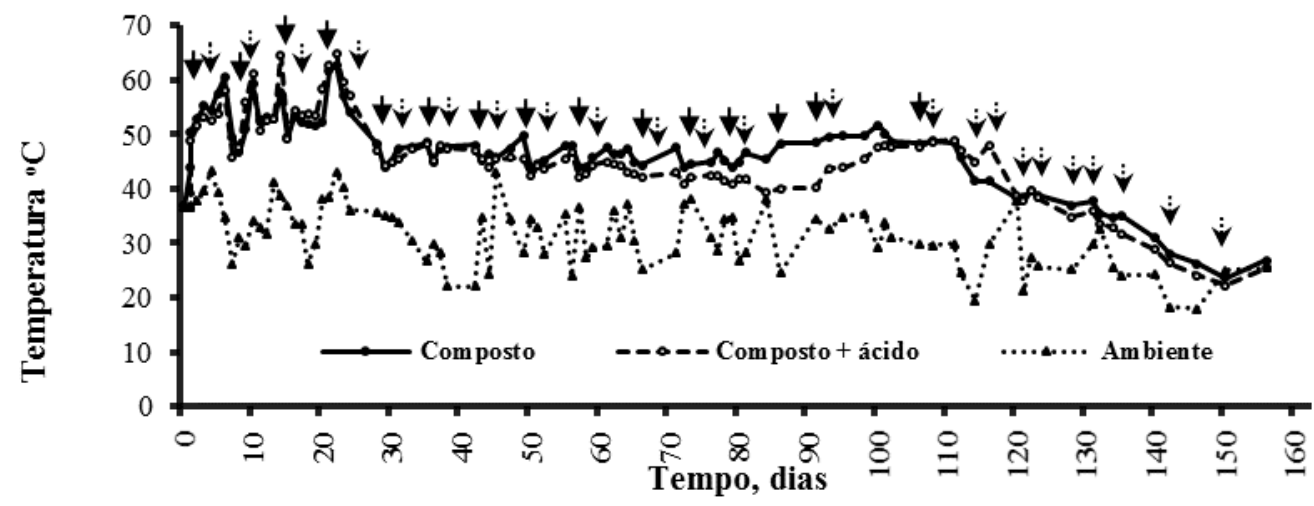

Figura 2. Variação média da temperatura do ambiente e das leiras de compostagem, onde dejetos líquidos de suínos (DLS), com e sem a adição de ácido fosfórico, foram adicionados à mistura de maravalha + serragem como substrato. As setas com linhas cheias indicam adição dos DLS e revolvimento das leiras, e as pontilhadas somente revolvidas durante o processo de compostagem. 
Um resultado a destacar refere-se à comparação da temperatura entre as leiras com e sem a adição de ácido fosfórico. Observa-se na Fig. 2 que, no período entre 50 e 100 dias, houve uma tendência da leira do composto sem ácido em apresentar maiores valores de temperatura do que a leira com ácido. Entre 80 e 100 dias, essa diferença média foi de $6^{\circ} \mathrm{C}$. Esse resultado indica que, neste período da segunda fase do processo de compostagem, a atividade microbiana foi afetada negativamente pela adição do ácido, liberando menos calor. A questão que se coloca é sobre as causas que determinaram a ocorrência deste efeito tão tardiamente. É provável que, nesta segunda fase do processo, a estrutura da população microbiana envolvida na decomposição dos constituintes do substrato e dos dejetos tenha diferido entre as leiras com e sem a adição de ácido.

Quanto à umidade, que era de apenas $6,3 \%$ no substrato, ela atingiu valores próximos a $60,0 \%$ já na primeira adição de DLS (Fig. 3). Isso ocorreu pelo fato de os dejetos líquidos apresentarem $99,8 \%$ de umidade. A umidade das leiras aumentou gradativamente até atingir cerca de $78,0 \%$ ao final do primeiro mês, mantendo-se próxima deste valor até 106 dias, mediante a adição semanal de dejetos. A partir do momento em que cessou a adição de dejetos e as pilhas foram submetidas apenas ao revolvimento duas vezes por semana, nota-se que a umidade de ambas as pilhas diminuiu em, aproximadamente, $3,0 \%$. A expectativa era de uma redução maior com os revolvimentos frequentes, o que pode não ter ocorrido em razão da redução observada na temperatura neste período (Fig. 2), a qual deve ter reduzido a evaporação d'água. $\mathrm{O}$ teor final de umidade das pilhas, de $75,0 \%$, é próximo ao encontrado por Leite et al. (2003), de 77,1\%, e por Leal (2006), de 71,9\%.

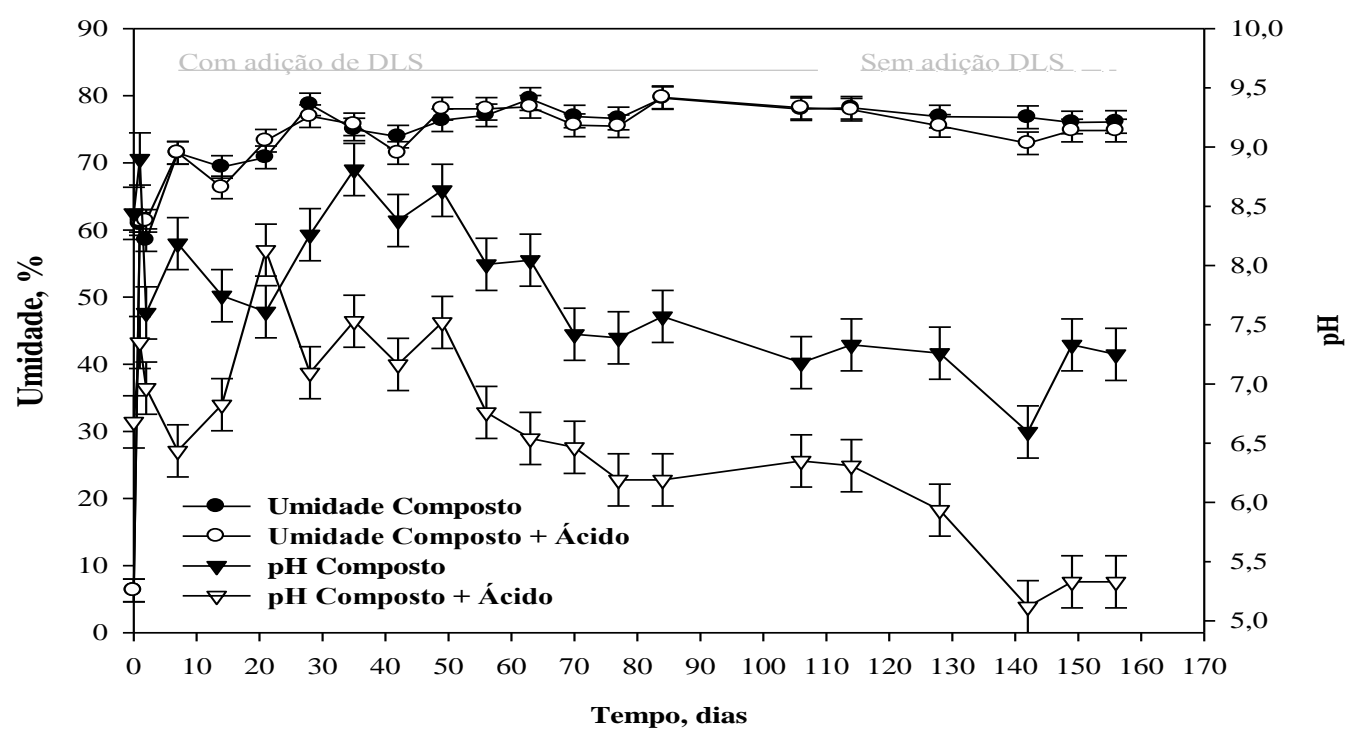

Figura 3. Variação da umidade e do $\mathrm{pH}$ ao longo do processo de compostagem nos tratamentos com e sem adição de ácido. As barras de erro representam o erro-padrão da média.

Com o aparecimento de chorume nas leiras após a segunda adição de dejetos, optou-se por reduzir gradualmente a quantidade de DLS aplicados a cada semana (Tab. 1). Na maioria das adições de dejetos, quantificou-se a população de coliformes totais (CT) e fecais (CF) nos dejetos sem e com adição de ácido fosfórico. Os resultados das Fig.
1 e 4 e da Tab. 1 indicam que não houve diferença no número de coliformes entre os dejetos com e sem adição de ácido fosfórico. Sem a adição de ácido, a população média de CF foi de $5,72 \pm 0,5\left(\log _{10} \mathrm{NMP} \mathrm{g}^{-1}\right)$ enquanto com

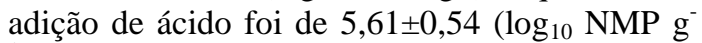
$\left.{ }^{1}\right)$. Isso evidencia que as duas leiras receberam 
concentrações semelhantes de coliformes em cada adição de dejetos. Conforme observado para os coliformes totais (Fig. 1), os coliformes fecais também estavam presentes no substrato, mesmo antes da adição dos dejetos. Nessa condição, a população inicial era de $1,4\left(\log _{10}\right.$ NMP $\mathrm{g}^{-1}$ ), evidenciando que o substrato pode ter sido contaminado com $\mathrm{CF}$, tanto na serraria onde foi coletado como durante o seu transporte ou até mesmo durante os procedimentos analíticos do material no laboratório. Isso porque a presença de $\mathrm{CF}$ em matrizes ambientais, como, por exemplo, na mistura de serragem e maravalha utilizada no experimento, indica que este material orgânico teve contato com animais de sangue quente ou de humanos, cujo trato digestivo é habitado por $\mathrm{CF}$.

Após a primeira adição de dejetos, cuja população inicial era de $6,52\left(\log _{10} \mathrm{NMP} \mathrm{g}^{-1}\right)$, esta aumentou para 6,0 $\left(\log _{10} \mathrm{NMP} \mathrm{g}^{-1}\right)$ no tratamento com adição de ácido fosfórico e para $4,9\left(\log _{10} \mathrm{NMP} \mathrm{g}^{-1}\right)$ no tratamento sem adição de ácido. No final do experimento, a população de CF no composto que recebeu dejetos sem adição de ácido fosfórico diminuiu para 1,3 $\left(\log _{10}\right.$ NMP $\left.\mathrm{g}^{-1}\right)$ e no composto com ácido para $0,4\left(\log _{10}\right.$ NMP $g^{-1}$ ).

Após o aumento inicial provocado pela adição dos dejetos, ocorreu uma redução acentuada na população de $\mathrm{CF}$ nos primeiros 35 dias, o que coincide com a fase termofílica da compostagem, em que a temperatura das leiras foi superior a $45^{\circ} \mathrm{C}$ (Fig. 2). Mesmo com a readição frequente de dejetos nessa fase, a população de $\mathrm{CF}$ diminuiu, o que pode ser atribuído aos valores desfavoráveis de temperatura para o crescimento de $\mathrm{CF}$, representados, no presente trabalho, por Escherichia coli. Quando a temperatura das leiras permaneceu em torno de $45^{\circ} \mathrm{C}$, no período entre 30 e 106 dias, não houve recuperação da população de CF para os níveis encontrados na segunda amostragem, realizada após a primeira adição de dejetos. Observa-se na Fig. 4 que a população de $\mathrm{CF}$ nos dejetos variou pouco no tempo, na faixa de 5 a $6\left(\log _{10} \mathrm{NMP} \mathrm{mL}^{-1}\right)$, na média dos tratamentos com e sem ácido. Portanto, pode-se especular que o fato de a população de CF não ter aumentado de forma consistente entre 35 e 106 dias, apesar das adições semanais de dejetos, seja resultado da temperatura ainda desfavorável, combinada a outros fatores, com destaque para a competição com outros microrganismos pelos nutrientes disponíveis.

$\mathrm{Na}$ primeira adição de dejetos realizada, os coliformes presentes neles devem ter sofrido pouca ou nenhuma competição com outros microrganismos pelo carbono e nutrientes dos próprios dejetos e, principalmente, pelo carbono do substrato. Todavia, o rápido aumento no crescimento e na atividade de outros microrganismos heterotróficos aumentou a temperatura das leiras de compostagem para níveis provavelmente desfavoráveis aos coliformes, além de aumentar a competição pelas fontes de nutrientes, carbono e energia. Turner (2002) sugere que fatores, tais como o conteúdo de umidade, a liberação de amônia e a atividade de outros microrganismos, exercem efeito inibitório sobre o desenvolvimento de microrganismos patogênicos em compostos.

Apesar das variações observadas na população de coliformes fecais durante a compostagem, observa-se na Fig. 4 que há uma tendência clara na redução da população deste grupo de bactérias, a partir do momento em que cessou a adição de dejetos nas leiras, aos 106 dias. Isso pode ser explicado pela não reinoculação semanal das leiras com bactérias contidas nos dejetos e pela exaustão das fontes de nutrientes, carbono e energia, além da redução gradativa da temperatura para valores subótimos (Fig. 2). Portanto, para que haja redução efetiva de colformes fecais nesse sistema de compostagem automatizada dos dejetos líquidos de suínos, parece de fundamental importância que haja um período no final do processo em que as leiras sejam apenas revolvidas, sem a readição de dejetos.

Com relação ao efeito da acidificação dos dejetos sobre a população de CF, observa-se na Fig. 4 que, até cessar a adição de dejetos nas leiras, quando houve diferenças, ela ocorreu sempre no mesmo sentido, com a leira que recebeu dejetos acidificados apresentando maior população. Por outro lado, após cessar a adição de dejetos, essa tendência se inverteu, com o tratamento sem adição de ácido fosfórico apresentando menos CF. É difícl estabelecer as causas para este resultado, já que a temperatura (Fig. 2) e a umidade (Fig. 3) não diferiram entre os dois compostos. 
O pH também não explica o resultado, uma vez que a variação ocorreu sempre no mesmo sentido, com o composto da leira que recebeu dejetos com ácido fosfórico apresentando, durante todo o experimento, valor de $\mathrm{pH}$ entre 1 e 1,5 unidade menor do que o composto sem ácido. De acordo com Chroni et al. (2009), o pH se correlaciona com o crescimento e desenvolvimento de microrganismos, incluindo E. coli, durante a compostagem, com valores baixos de $\mathrm{pH}$ podendo resultar na inibição do seu crescimento. Estes mesmos autores evidenciaram que, para valores de $\mathrm{pH}$ próximos a 9,0 ou acima, ocorre a morte de coliformes fecais, com valores de $\mathrm{pH}$ entre 5,5 e 8,3, permitindo a sobrevivência destes no material compostado. No presente trabalho, raramente os valores de $\mathrm{pH}$ de ambos os compostos apresentaram valores fora desta faixa.

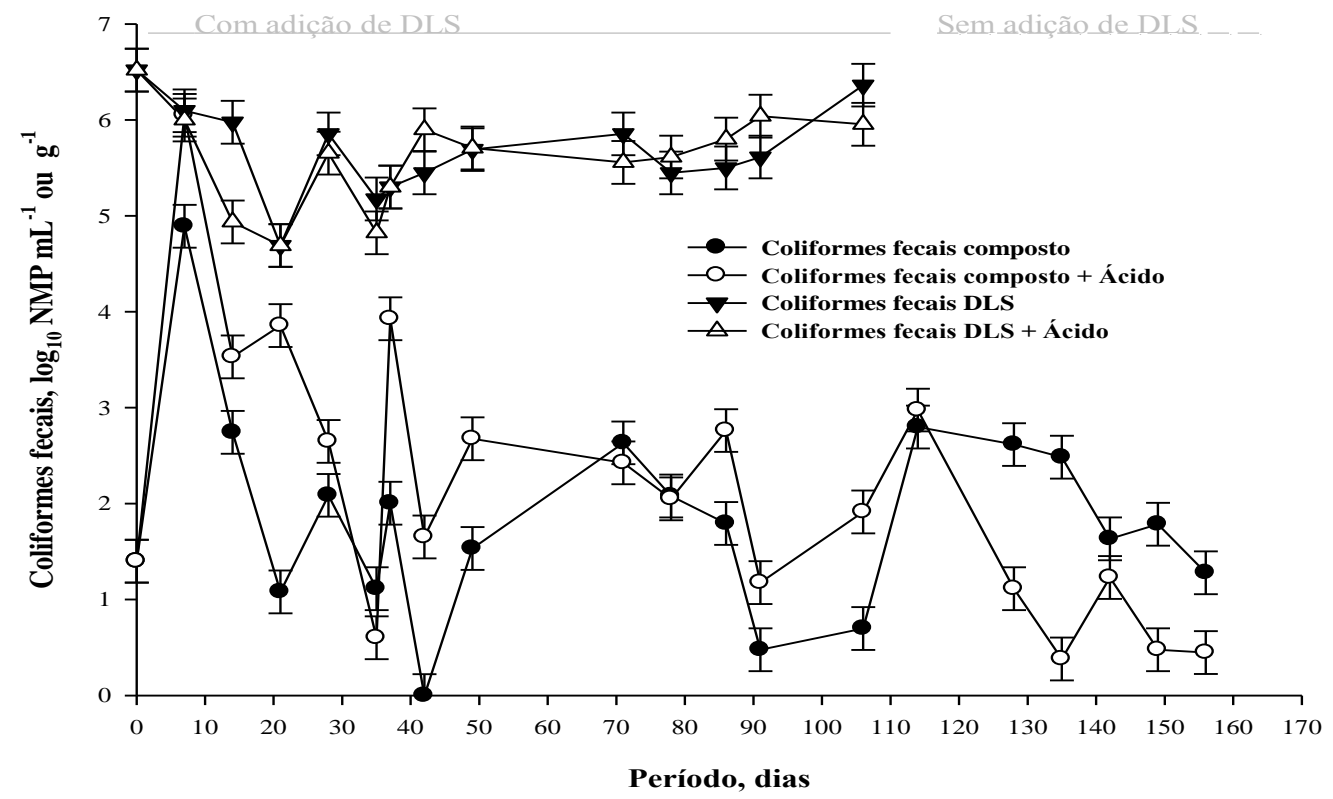

Figura 4. População de coliformes fecais (CF) em dejetos líquidos de suínos (DLS), com e sem adição de ácido fosfórico antes da sua aplicação nas leiras de compostagem, e população de CF no composto obtido. As barras de erro representam o erro-padrão da média.

Pode-se inferir, com base nos resultados deste trabalho, que a compostagem automatizada dos dejetos líquidos de suínos constitui uma estratégia eficiente na redução de tais microganismos, sem diferenças claras entre acidificar ou não os dejetos na maior parte da compostagem. O NMP total de coliformes fecais adicionados nas leiras com o DLS sem adição de ácido foi de 4,2 x $10^{10}$ e com adição de ácido 3,8 x $10^{10}$. Ao final do processo, aos 156 dias de compostagem, o NMP de coliformes fecais de 2,3 $\times 10^{4} \mathrm{NMP}^{-1}$ no composto com ácido e de $1,2 \times 10^{5} \mathrm{NMP} \mathrm{g}^{-1}$ no composto sem ácido ainda é superior ao limite estabelecido pelo Mapa (1,0 x $10^{3} \mathrm{NMP} \mathrm{g}^{-1}$; Brasil, 2006), para compostos classe A. Embora tenha ocorrido uma redução significativa (99,9 \%) em relação ao NMP de coliformes fecais presentes originalmente nos dejetos, é preciso intensificar os trabalhos na busca de alternativas que melhorem a eficiência da compostagem quanto à sanitização do composto final, de modo a atender a legislação vigente.

\section{CONCLUSÕES}

O tratamento dos dejetos líquidos de suínos por meio da sua compostagem automatizada propicia uma redução significativa na população de coliformes, indicadores de poluição fecal. 


\section{REFERÊNCIAS}

APHA, AWWA, EFA. Standard methods for the examination of water and waste water. American public Healt Association 20.ed. Washington, DC:p. 45-62, 2005.

BARROS, F.M.; MARTINEZ, M.A.; MATOS, A.T. et al. Mineralização de nitrogênio em dejetos de suínos. Enc. Biosf. Centro Científico Conhecer, v.7, p.1, 2011.

BRASIL. Ministério da Agricultura, Pecuária e Abastecimento. Instrução Normativa no 27, de 05 de junho de 2006. Diário Oficial da República Federativa do Brasil, Brasília, DF, 09 de junho de 2006. Seção 1, p.15.

CEMPIRKOVÁ R.; ŠOCH, M. The analysis of real microbiological risks for dissociated slurry. Agricult. Tropica et Subtropica, v.40, p.164-171, 2007.

CHRONI, C.H.; KYRIACOU, A.; MANIOS, T.; LASARIDI, K.E. Investigation of the microbial community structure and activity as indicators of compost stability and composting process evolution. Biores. Tech., v.100, p.3745-3750, 2009.

ELVING, J. Pathogen Inactivation and Regrowth in Organic Waste during Biological Treatment. Department of Chemistry, Environment and Feed Hygiene, National Veterinary Institute (SVA), SE-751-789, 2009.

FRANCO, B.D.G.M.; LANDGRAF, M. Microbiologia dos alimentos. São Paulo :Atheneu, , 2008. 182p.

JACOBSEN, C.S.; BECH, T.B. Soil survival of Salmonella and transfer to fresh water and fresh produce. Food Res. Internat., v.45, p.557-566, 2012.

KIEHL, E.J. Manual de compostagem: maturação e qualidade do composto. 4.Ed. do autor. Piracicaba: , 2004. 173p.

KIM, J.; LUO, F.; JIANG, X. Factors impacting the regrowth of Escherichia coli $\mathrm{O} 157: \mathrm{H} 7$ in dairy manure compost. J. Food Prot., v.72, p.1576-1584, 2009.
LEAL, M.A.A. Produção e eficiência agronômica de compostos obtidos com palhada de gramínea e leguminosa para o cultivo de hortaliças orgânicas. 2006, 133f. Tese (Doutorado em Agronomia- Ciência do Solo) Universidade Federal Rural do Rio de Janeiro Seropédica.

LEITE, V.D.; SOUSA, J.T.; PRASAD, S. et al. Tratamento de resíduos sólidos de centrais de abastecimento e feiras livres em reator anaeróbio de batelada. Rev. Bras. Eng. Agr. Amb., v.7, p.318-322, 2003.

PERDOMO, C.C.; OLIVEIRA, P.A.V.O.; KUNZ, A. Sistema de tratamento de dejetos de suínos: inventário tecnológico. Embrapa Suínos e Aves, 2003. 83p. (Documentos, 85).

SANTANA, L.R.R.; CARVALHO, R.D.S.; LEITE, C.C. et al. Qualidades físicas, microbiológicas e parasitológicas de alfaces (Lactuca sativa) de diferentes sistemas de cultivo. Rev. Cienc. Tecnol. Alimentos, v.26, p.264-269, 2006.

SAS INSTITUTE. 2003. SAS System: SAS/STAT version 9.1 (software). Cary.

SEMENOV, A.M.; KUPRIANOV, A.A.; van BRUGGEN A.H.C. Transfer of Enteric Pathogens to Successive Habitats as Part of Microbial Cycles. Environ. Microbiol., v.60, p.239-249, 2010.

TURNER, C. The thermal inactivation of E. coli in straw and pig manure. Biores. Techn., v.84, p.57-61, 2002.

VALENTE, B.S.; XAVIER, E.G.; MORSELLI, T.B.G.A. et al. Fatores que afetam o desenvolvimento da compostagem de resíduos orgânicos. Arch. Zootec., v.58, p.59-85, 2009.

WONG, J.W.C.; SELVAM, A. Reduction of indicator and pathogenic microorganisms in pig manure through fly ash and lime addition during alkaline stabilization. J. Haz. Mat., v.169, p.882889, 2009. 